\title{
АНАМИЗ ПЕРСПЕКТИВЫ СОЗДАНИЯ ПРОЕКТНОГО ОФИСА СТУДЕНТОВ
}

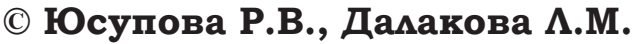 \\ ФГБОУ ВО «ГГНТУ им. акад. М. Д. Миллионщчикова», \\ 2. Грознылй
}

\begin{abstract}
| В данной статье проводится анализ перспективы создания проектного офиса студентов. Проектный офис студентов это среда, в которой студенты по новой программе научатся применять практики по созданию проектов и сопровождению проектной деятельности, раскрывать понятие проекта, определять проблему и идею проекта, организовывать командную работу участников. Организация такой площадки направлена на развитие у студентов компетенций в различных областях знаний, в том числе и востребованные навыки soft skills.
\end{abstract}

Ключевые слова: образование, проектный офис, студенты, проектная деятельность.

Российская Федерация постепенно становится открытой страной, которая строит рыночную экономику и правовое государство. Одновременно с этим увеличивается ответственность человека за собственное благополучие. Россия, как и любая страна, нуждается во всесторонне развитых и высококвалифицированных специалистах, способных принимать самостоятельные ответственные решения в условиях быстро меняющегося мира, что, безусловно, предъявляет особые требования к системе образования.

Реформы в системе образования происходят с завидной регулярностью. Но в основном все они в большей степени касаются содержания образования, а не структуры и формы управления образовательным учреждением. Федеральный закон об образовании говорит о том, что образовательная организация должна быть открыта и прозрачна, федеральные образовательные стандарты акцентируют внимание на компетенциях студентов в сфере информационных технологий и проектной деятельности; новые профессиональные стандарты подразумевает определенный уровень владения как современными информационными 
технологиями, так и технологиями проектной деятельности. Проектный метод способствует реализации личностно-ориентированного подхода и гуманизации учебно-воспитательного процесса. Главной задачей подготовки будущих преподавателей к проектной деятельности является обучение их созданию развивающей среды, условий для эффективного развития личности каждого студента, при которых учащийся рассматривается как активный участник процесса познания, а не как объект, пассивно воспринимающий информацию. Использование метода проектов позволяет не на словах, а на деле реализовать деятельностный подход, способствовать применению знаний и умений, полученных при изучении различных дисциплин на разных этапах обучения, и интегрировать их в процессе работы над проектом. На сегодняшний день, преподаватели высших учебных заведений и организаций среднего профессионального образования не в полной мере владеют технологиями исследовательской и проектной деятельности, большинство преподавателей не спешат вовлекать студентов в исследовательскую и проектную работу. Происходит это по той причине, что при переходе на новую систему оплаты труда (эффективный контракт) вознаграждение из стимулирующего фонда выплачивается только за призовые места, занятые студентами на конкурсе, а сам трудоемкий и сложный процесс подготовки работы не оплачивается. Если студенты не заняли призового места, преподаватель остается без выплат. С материальной точки зрения преподавателю выгоднее заниматься репетиторством, занимаясь один час в неделю с группой сильных студентов, подготовить их к олимпиаде или сдаче экзаменов, чем тратить много времени и сил на проведение исследования или подготовку проекта, успех которых не гарантирован. В школах процесс организации проектной деятельности так же не приносит желаемых результатов, так как оплата производится только при условии, что проект юных исследователей займет призовое место. Учителя школ, принимая во внимание недоработанную материальную сторону вопроса, занимаются подготовкой группы школьников к предметным олимпиадам и сдаче единого государственного экзамена.

Создание проектного офиса студентов позволит создать среду, в которой студенты по новой программе научатся применять практики по созданию проектов и сопровождению проектной 
деятельности, раскрыть понятие проекта и точно определить проблему и идею проекта, организовать командную работу участников. Участники узнают, как просчитать финансовую сторону проекта и его прибыльность. В процессе исследовательской и проектной деятельности у студентов сформируется круг познавательных интересов, что будет способствовать развитию soft-skills. Это работа в команде, креативное мышление, эмоциональный интеллект, презентации и сторителлинг (навык красиво излагать информацию в интернет-пространстве). Планируется обучение в несколько последовательных этапов. В рамках проектной работы на проектных сессиях модератор расскажет о трендах и технологиях мира в будущем. После этого проектные команды под руководством профессионального модератора смогут самостоятельно определить сферу и направление, которые интересны именно им, актуальны в краткосрочной и среднесрочной перспективе. В этом направлении слушатели и будут создавать проект. В процессе решения поставленных задач у студентов развиваются интеллектуальные и творческие способности, самостоятельность, исследовательские и информационные умения. В ходе представления работы приобретается опыт публичного выступления, аргументированного отстаивания собственного мнения. Таким образом, участие в исследовательской и проектной деятельности способствует достижению студентами личностных, метапредметных и общих предметных результатов, происходит их подготовка к обоснованному выбору дальнейшего жизненного пути в соответствии с собственными интересами и возможностями. Программа обучения в проектном офисе студентов создана с учетом требований стандартов по управлению проектами и соответствует ФГОС по проектной деятельности в вузе и организациях СПО. Она будет реализовываться в соответствии со стратегическими целями и государственными программами развития отраслей экономики региона.

Среди задач реализации проекта можно выделить несколько важных позиций:

1. Формирование нормативных и организационно-методических условий системной деятельности по созданию и функционированию проектного офиса студентов;

2. Определение возможного контингента обучаемых проектного офиса с использованием различных форм привлечения; 
3. Подбор помещений (коворкинга), позволяющих реализовать потребности и запросы контингента;

4. Открытие проектного офиса студентов;

5. Привлечение к преподаванию представителей отраслевых объединений, преподавателей ведущих проектную деятельность, управленцев и специалистов в сфере проектного менеджмента, сотрудников общественных организаций и государственных органов, независимые эксперты;

6.Проведение обучающих проектных сессий, мастер-классов, тренингов. Методическое, консультационное, организационное и информационное сопровождение проектов студентов и преподавателей с момента формирования идеи и до полной его реализации в виде проекта;

7. Массовая трансляция в информационной и молодежной среде итоговых решений и моделей.

При реализации проекта используются следующие методы работы:

1. Методическая деятельность:

- подготовка нормативных и учебно-методических документов;

2. Организационная деятельность:

- определение возможного контингента обучаемых проектного офиса с использованием различных форм привлечения;

- рассылку информационных писем и формы заявки на участие;

- подбор помещений (коворкинга), позволяющих реализовать потребности и запросы контингента;

- прием и обработку заявок;

- взаимодействие с участниками, прошедшими отбор;

- подготовку полиграфических и раздаточных материалов;

- фото- и видеосъемку;

- проведение обратной связи с участниками.

3. Экспертная и тьюторская деятельность:

- сопровождение и консультирование смысловой содержательной части мероприятий;

- проведение обучающих проектных сессий, мастер-классов, тренингов. Методическое, консультационное, организационное и информационное сопровождение проектов студентов и преподавателей с момента формирования идеи и до полной его реализации в виде проекта. 
4. Образовательная деятельность:

- подготовку и проведение программы образовательной программы по проектной деятельности;

- формирование рефлексии;

- проведение ярмарки проектов.

5.Информационная деятельность:

- разработка фирменного стиля;

- продвижение в социальных сетях, на информационные порталах и СМИ;

Получение положительных результатов при создании проектного офиса реально, если проектная деятельность изначально верно организована, выбрана успешная тематика проектных заданий, эффективные методы и организационные формы их решения, заданы реальные сроки выполнения, создана учебно-материальная база, осуществляется систематический контроль над выполнением проектов со стороны педагога, вырабатываются новые методики создания и ведения проектов.

По итогу в проектную деятельность будут вовлечены студенты и преподаватели способные заниматься научно-техническим творчеством и изобретательством, производственной и предпринимательской деятельностью, обеспечивать экономический рост региона на основе активного использования новейших достижений теоретической науки, методических и научно-практических разработок, учёта международных стандартов.

\section{Мнтература}

1. Гуревич П. С. Психология и педагогика: Учебник и практикум для академического бакалавриата. М.: Юрайт, 2019. $430 \mathrm{c}$.

2. Дрозд К. В. Актуальные вопросы педагогики и образования: Учебник и практикум для академического бакалавриата. М.: Юрайт, 2019. 266 с.

3. Рожков М. И., Макеева Т. В. Социальная педагогика: Учебник для академического бакалавриата. М.: Юрайт, 2017. 288 с.

4. Суртаева Н. Н. Педагогика. педагогические технологии: Учебное пособие для СПО. М.: Юрайт, 2019. 250 с. 